\title{
Peptides in fermented Finnish milk products
}

\author{
Minna Kahala, Eero PahKala and Anne Pihlanto-Leppälä
}

Kahala, M., Pahkala, E. \& Pihlanto-Leppälä, A. 1993. Peptides in fermented Finnish milk products. Agric. Sci. Finl. 2: 379-386. (Agric. Res. Centre of Finland, Food Res. Inst., FIN-31600 Jokioinen, Finland.)

This study was conducted to investigate the rate of proteolysis and peptide profiles of different Finnish fermented milk products. The highest rate of proteolysis was observed in Biokefir, while the greatest change in the rate of proteolysis was observed in Gefilus $($. Differences in starters and manufacturing processes reflected on the peptide profiles of the products. Most of the identified peptides originated from either the $\mathrm{N}$ - or $\mathrm{C}$-terminal region of $\beta$-casein or from the $\mathrm{N}$-terminal region of $\alpha_{\mathrm{s} 1}$-casein.

Key words: fermented milk products, proteolysis, peptides

\section{Introduction}

The enzymatic degradation of milk proteins yields amino acids and peptides of varying size. The quality and quantity of the products of degradation depend on the components of the milk protein fraction and the enzymes involved, i.e. bacterial proteases and plasmin. The temperature and $\mathrm{pH}$ of the processes and products also have their effect on the liberation of amino acids and peptides.

The starters of fermented milk products contain proteolytic enzymes, which cause proteolysis during manufacture and storage. The products formed by proteolysis have a great effect on the final product. They can contribute to its texture, nutritional properties and flavour of the product. Peptides and amino acids are not solely responsible for the flavour, but they can act as precursors of the flavourproducing enzymatic reactions (TAMINE and RoBINSON 1989). Certain peptides contribute to a bitter taste in the product. The formation of bitter peptides in the manufacture of yoghurts is favoured by a temperature below $38^{\circ} \mathrm{C}$ as well as by the activity of the enzymes during cold storage (ROBINSON and TAMINE 1981).

Only a few reports have been published on the peptide content of fermented milk products. TANEV and ZivKova (1977) investigated the peptide content of milk and Bulgarian yoghurt during storage using an electrophoretic method. Free amino acids have been the subject of several studies (MILLER et al. 1964, ALm 1982). Also, the degradation of casein components with different lactic acid bacteria has been studied by PAHKALA et al. (1989a, 1989b)

The aim of this study was to investigate the peptide profiles of various fermented milk products with high performance liquid chromatography (HPLC) methods.

\section{Material and methods}

The investigated fermented milk products were Gefilus ${ }^{\circledR}$, plain yoghurt, Bulgarian yoghurt, viili, soured skimmed milk, acidophilus milk and Biokefir. The samples were obtained from two dairies in 
Table 1. Micro-organisms used in the fermented milk products.

\begin{tabular}{|c|c|c|}
\hline Product & Starter type & Micro-organisms \\
\hline 1. Bulgarian yoghurt & thermophilic & $\begin{array}{l}\text { Streptocoocus salivarius ssp. } \\
\text { thermophilus, Lactobacillus } \\
\text { delbrueckii ssp. bulgaricus }\end{array}$ \\
\hline 2. Plain yoghurt & thermophilic & $\begin{array}{l}\text { Streptocoocus salivarius ssp. } \\
\text { thermophilus, Lactobacillus } \\
\text { delbrueckii ssp. bulgaricus }\end{array}$ \\
\hline 3. Gefilus & mixed mesophilic + special & $\begin{array}{l}\text { Lactococcus lactis ssp. lactis, L. } \\
\text { lactis } \mathrm{ssp} . \text { cremoris, L. lactis ssp. } \\
\text { lactis biovar. diacetylactis, } \\
\text { Leuconostoc mesenteroides ssp. } \\
\text { cremoris, Lactobacillus GG }\end{array}$ \\
\hline 4. Viili & mixed mesophilic + special & $\begin{array}{l}\text { Lactococcus lactis } \mathrm{ssp} . \text { lactis, } L . \\
\text { lactis } \mathrm{ssp} . \text { cremoris, L. lactis } \mathrm{ssp} \text {. } \\
\text { lactis biovar. diacetylactis, } \\
\text { Leuconostoc mesenteroides } \mathrm{ssp} . \\
\text { cremoris, Geotrichum candidum }\end{array}$ \\
\hline 5. Biokefir & mixed mesophilic + special & $\begin{array}{l}\text { Lactococcus lactis } \mathrm{ssp} . \text { lactis, } L . \\
\text { lactis } \mathrm{ssp} . \text { cremoris, L. lactis } \mathrm{ssp} \text {. } \\
\text { lactis biovar. diacetylactis, } \\
\text { Leuconostoc mesenteroides ssp. } \\
\text { cremoris, Kefir grains }\end{array}$ \\
\hline 6. Acidophilus milk & mixed mesophilic + special & $\begin{array}{l}\text { Lactococcus lactis ssp. lactis, L. } \\
\text { lactis ssp. cremoris, L. lactis ssp. } \\
\text { lactis biovar. diacetylactis, } \\
\text { Leuconostoc mesenteroides } \mathrm{ssp} . \\
\text { cremoris, Lactobacillus acidophilus }\end{array}$ \\
\hline 7. Soured skimmed milk & mixed mesophilic & $\begin{array}{l}\text { Lactococcus lactis } \mathrm{ssp} . \text { lactis, } L . \\
\text { lactis } \mathrm{ssp} . \text { cremoris, L. lactis } \mathrm{ssp} \text {. } \\
\text { lactis biovar. diacetylactis, } \\
\text { Leuconostoc mesenteroides } \mathrm{ssp} . \\
\text { cremoris }\end{array}$ \\
\hline
\end{tabular}

southern Finland and stored at $+4^{\circ} \mathrm{C}$ during the study period. The micro-organisms used in the manufacture of these fermented milk products are listed in Table 1.

\section{Sample preparation}

The proteins and larger peptides were precipitated with $6 \%$ trichloroacetic acid (TCA). The supernatant was centrifuged at $+7^{\circ} \mathrm{C}$ for 15 minutes and $6000 \mathrm{G}$ and filtered through a $0.45 \mu \mathrm{m}$ filter.

The samples were precipitated on the second and eighth day after manufacture as well as on the sell-by date. The proteolysis was monitored by determining the total nitrogen in the product and in the filtrate with the Kjeldahl method.

\section{Separation of peptides with HPLC}

The HPLC equipment consisted of two pumps (Waters 510), an automatic sample processor (Waters Wisp 710), a UV detector (Pharmacia LKB VWM 2141) and a personal computer (NEC APV IV) with an analysis programme (Waters Baseline 810). The column was SuperPac Pep-S (4.0 x 250 $\mathrm{mm}, 5 \mu \mathrm{m}$; Pharmacia LKB) equipped with precol- 
umn Pep-S (4.0 x 10 mm, $5 \mu \mathrm{m}$; Pharmacia LKB). The column temperature was $30^{\circ} \mathrm{C}$ and flow rate $1.0 \mathrm{ml} / \mathrm{min}$. The eluants were: A $0.05 \%$ trifluoroacetic acid (TFA) in water and B $0.05 \%$ TFA, $90 \%$ acetonitrile $\left(\mathrm{CH}_{3} \mathrm{CN}\right)$ in water. The gradient grew linearly from $2 \%$ to $60 \% \mathrm{~B}$ in 45 minutes.

Before HPLC analysis the samples were filtered once again through a $0.45 \mu \mathrm{m}$ filter. The injection volume was $100 \mu \mathrm{l}$ and the peptides were detected at wavelengths of 214 and $280 \mathrm{~nm}$. The peptides were collected manually after the detector.

\section{Peptide identification and amino acid analysis}

After collection the peptides were dried under vacuum. The total amino acid content and the N-terminal sequence of three amino acid residues were determined for each peptide. Free amino acids were analyzed in the TCA soluble fraction. The peptides were hydrolyzed for the total amino acid analysis in gas phase $(6 \mathrm{~N} \mathrm{HCl}+1 \%$ phenol $)$ at $110^{\circ} \mathrm{C}$ for 24 hours. The amino acids were analyzed as phenyltiocarbamate (PTC) derivatives using the Waters Pico Tag method. The preparation of the derivatives and the HPLC analysis were performed according to the instructions of Millipore Corporation (1987). The equipment was the same as in the peptide analysis, except that the column was Waters Pico Tag $(3.9 \times 150 \mathrm{~mm})$ and the temperature $40^{\circ} \mathrm{C}$.

The manual $\mathrm{N}$-terminal sequence analysis was performed according to the method of TARR (1986). Phenyltiohydantoin (PTH) amino acids were analyzed with the above-mentioned HPLC equipment on a Waters Pico Tag column. The running conditions were according to LEMIEUX and Аміот (1990),

\section{Results and discussion}

Table 2 shows the change in the rate of proteolysis of the different fermented milk products between the first day and the sell-by date. In each product the rate of proteolysis increased during the storage period. The greatest change after one week of storage was observed in Gefilus $(+2.3 \%)$, while there was
Table 2. Rate of proteolysis $(\%)$ in fermented milk products during storage. $(6 \%$ TCA soluble $\mathrm{N} /$ total $\mathrm{N} \times 100)$.

\begin{tabular}{lrrrr}
\hline \multirow{2}{*}{ Product } & \multicolumn{4}{c}{ age } \\
\cline { 2 - 5 } & 1 day & 7 days & $\begin{array}{c}\text { sell-by } \\
\text { date }\end{array}$ \\
\hline 1. Bulgarian yoghurt & 6.3 & 7.8 & 8.5 & $(15)$ \\
2. Plain yoghurt & 6.8 & 7.7 & 8.1 & $(14)$ \\
3. Gefilus & 6.2 & 8.3 & 8.5 & $(18)$ \\
4. Viili & 8.2 & 9.4 & 9.6 & $(13)$ \\
5. Biokefir & 9.1 & 9.5 & 10.1 & $(13)$ \\
6. Acidophilus milk & 8.0 & - & 9.6 & $(11)$ \\
7. Soured skimmed milk & 7.8 & - & 8.1 & $(10)$ \\
\hline
\end{tabular}

only a slight change in soured skimmed milk after 10 days of storage. The highest rate of proteolysis was found in Biokefir both at the age of one day and on the sell-by date.

Figures 1-7 show the peptide profiles of the different fermented milk products at the age of one day and on the sell-by date. The suggested sequence of the identified peptides is also indicated. Figure 8 shows the peptide profile of a pasteurized milk sample on the day of manufacture and after four days' cold storage.

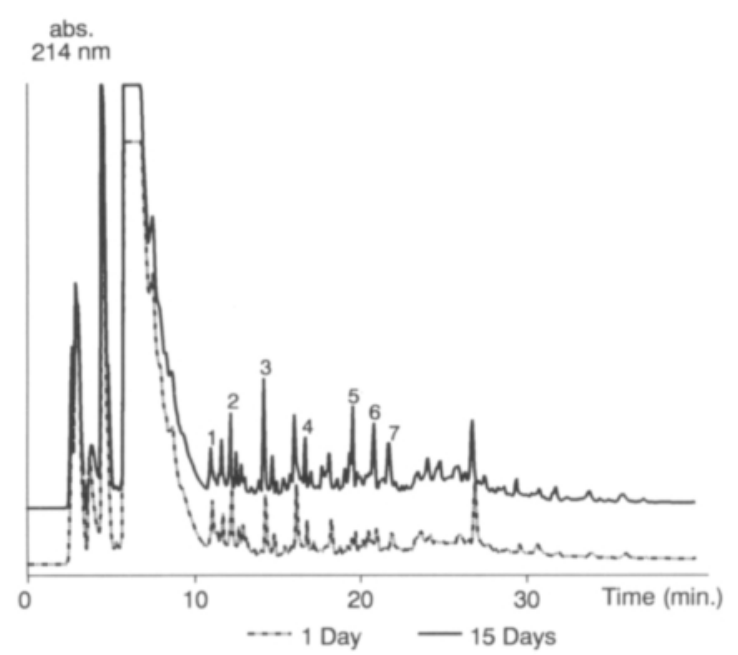

Fig. 1. Peptide profile of Bulgarian yoghurt at the age of 1 and 15 days. Identified fractions: 1. Leu, 2. Tyr, 3. Phe, 4. $\alpha_{\text {s1 }}-\mathrm{CN} 1-14,5$. $\beta-\mathrm{CN} 47-57,6$, $\beta-\mathrm{CN} 166-175,7$. $\beta-\mathrm{CN}$ 176-188. 


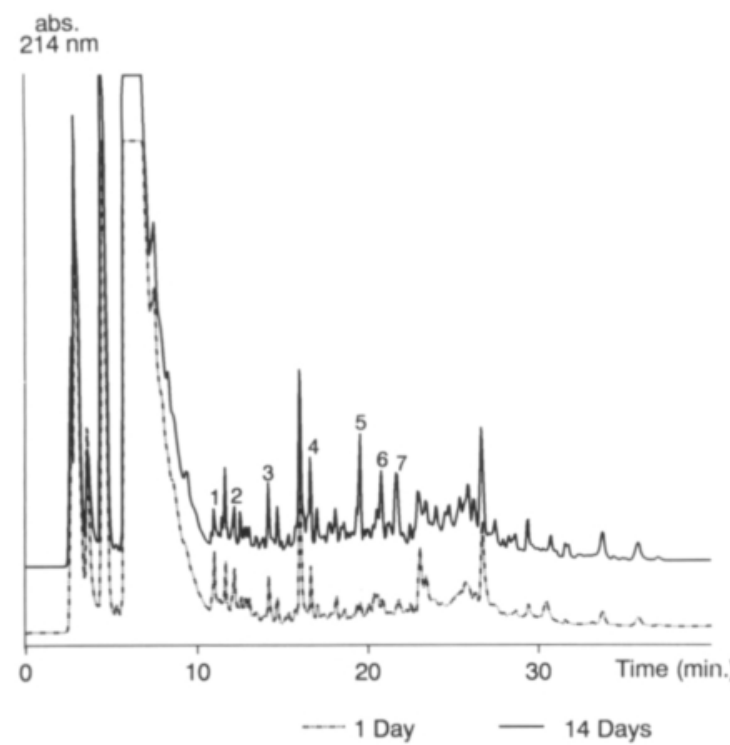

Fig. 2. Peptide profile of plain yoghurt at the age of 1 and 14 days. Identified fractions: 1. Leu, 2. Tyr, 3. Phe, 4. $\alpha_{\mathrm{s} 1}-\mathrm{CN}$ $1-14,5$. $\beta-\mathrm{CN} 47-57,6$. $\beta-\mathrm{CN} 166-175,7 . \beta-\mathrm{CN} 176-188$.

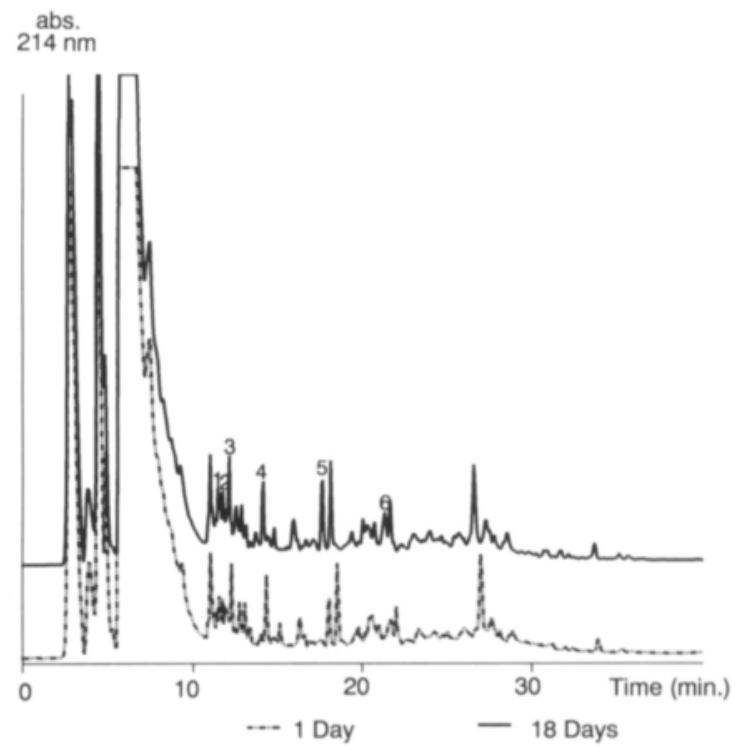

Fig. 3. Peptide profile of Gefilus at the age of 1 and 18 days. Identified fractions: 1. Ile, 2. Leu, 3. Tyr, 4. Phe, 5. $\beta-\mathrm{CN}$ 176-182, 6. $\beta-\mathrm{CN} 7-15$.

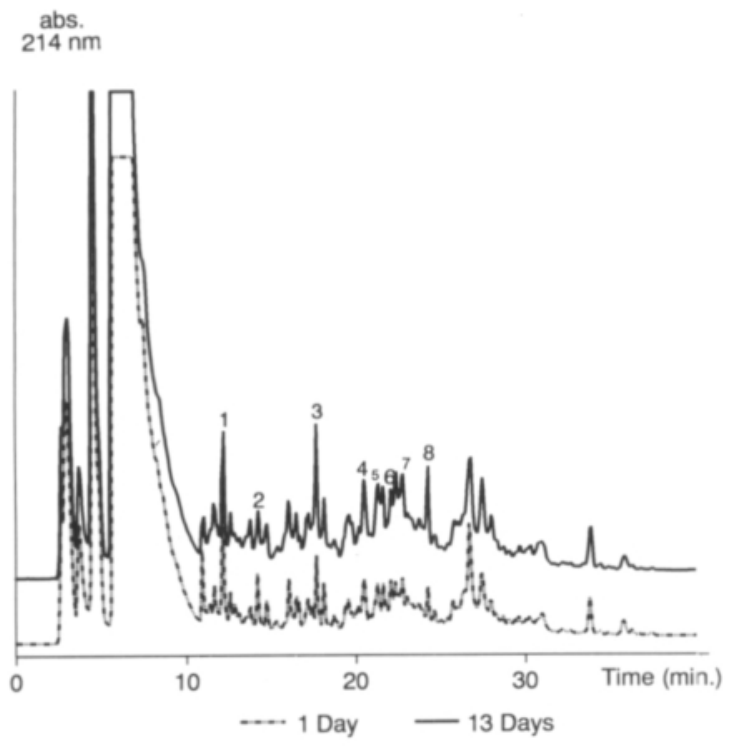

Fig. 4. Peptide profile of viili at the age of 1 and 13 days. Identified fractions: 1 . Tyr, 2. Phe, 3. $\beta-\mathrm{CN} 176-182,4$. $\beta-\mathrm{CN}$ $169-175,5$. $\beta-\mathrm{CN} 7-15,6 . \beta-\mathrm{CN} 1-9,7 . \beta-\mathrm{CN} 44-52$.

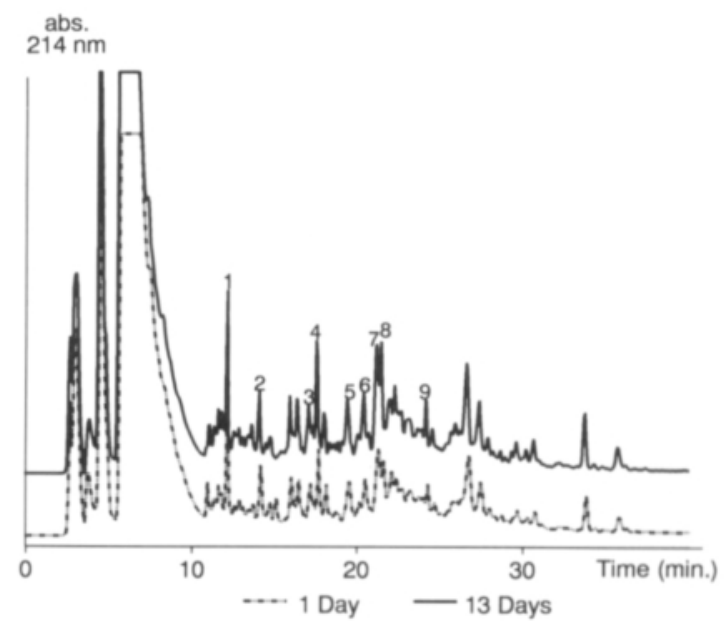

Fig. 5. Peptide profile of biokefir at the age of 1 and 13 days. Identified fractions: 1 . Tyr, 2. Phe, 3. $\beta-\mathrm{CN} 22-28,4$. $\beta-\mathrm{CN}$ 176-182, 5. $\beta$-CN 47-57, 6. $\beta-\mathrm{CN} 169-175,7, \beta-\mathrm{CN} 7-15,8$. $\beta-\mathrm{CN} 1-9,9 . \beta-\mathrm{CN}$ 44-52. 


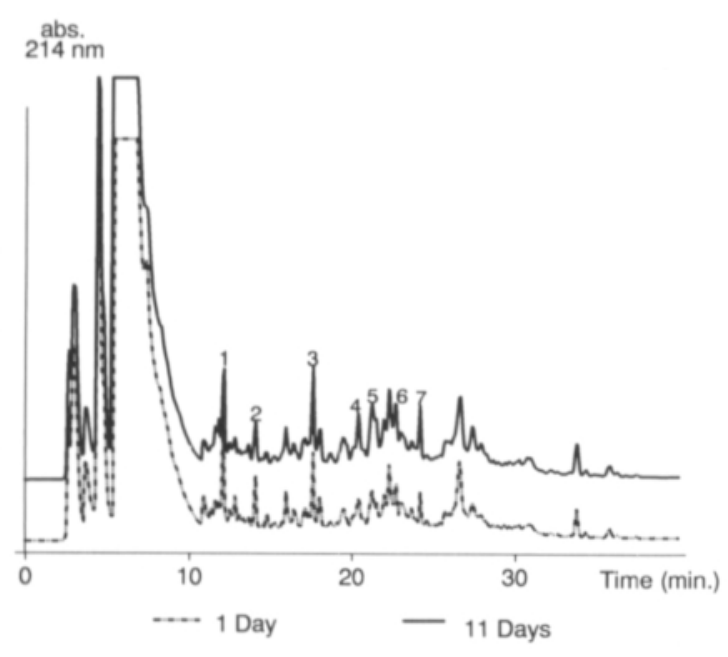

Fig. 6. Peptide profile of acidophilus milk at the age of 1 and 11 days. Identified fractions: 1. Tyr, 2. Phe, 3. $\beta-\mathrm{CN} 176-$ 182,4 . $\beta-\mathrm{CN} 169-175,5$. $\beta-\mathrm{CN} 7-16,6$. $\beta-\mathrm{CN} 164-175,7$. $\beta-\mathrm{CN}$ 44- 52.

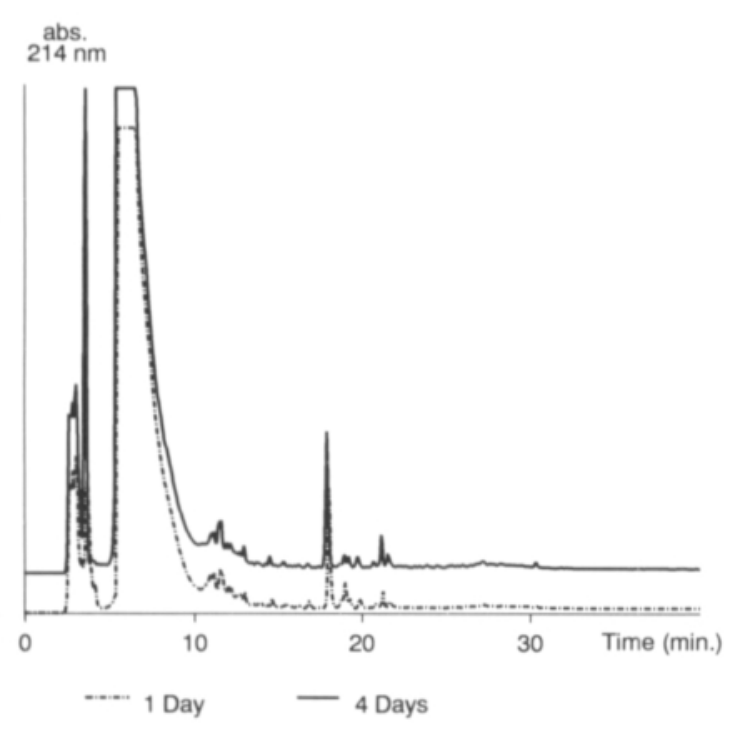

Fig. 8. Peptide profile of pasteurized milk at the age of 1 day and after 4 days' storage.

A wide peak caused by TCA can be seen at the beginning of each chromatogram. This is followed by the peaks of free amino acids and peptides. Only a few peaks are found on the chromatogram of pasteurized milk (Figure 8). A comparison between

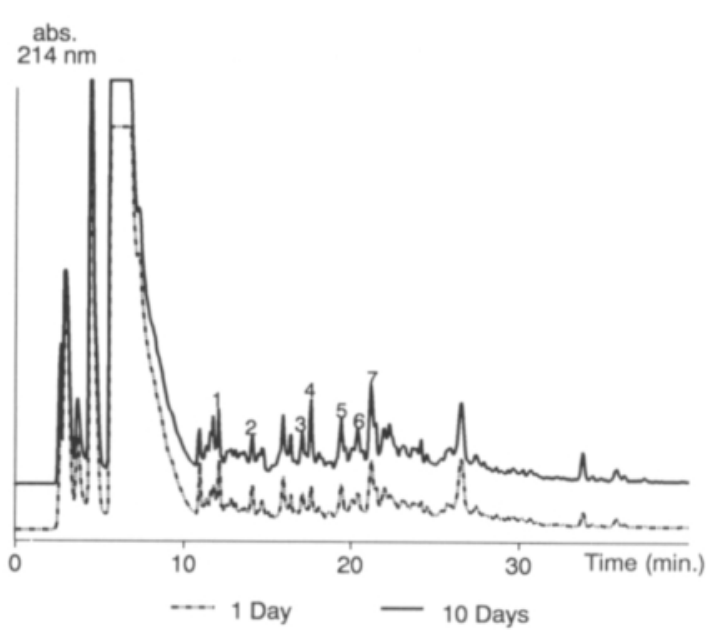

Fig. 7. Peptide profile of soured skimmed milk at the age of 1 and 10 days. Identified fractions: 1 . Tyr, 2. Phe, 3. $\beta-\mathrm{CN}$ 22-28, 4. $\beta$-CN 176-182, 5. $\kappa-\mathrm{CN} 161-169,6$. $\beta$-CN 169-175, 7. $\beta-\mathrm{CN} 7-15$.

fermented milk products and pasteurized milk shows the great effect of the fermentation process on the peptide content of the product. Also, the increase in both the height and area of the peptide peaks after storage gives information on the intensity of proteolysis.

In the free amino acid determinations, a high content of proline compared to other amino acids was observed, showing the highest content of all amino acids in all the fermented milks except in Gefilus (Figures 9 and 10). Glutamine content was also high in the products. During the manufacture and storage the content of all amino acids and peptides increased. ALM (1982) also found great variations in the amino acid content of different products. In yoghurt the proline content was found to be higher than average. Kefir was rich in lysine and proline at that study.

Differences caused by starters during the fermentation process become obvious when the peptide profile and content of the products are compared. A clear difference was between yoghurts and other fermented milk products. Yoghurts contained peptides which could not be found in the other products. Most of the identified peptides in all products originated from $\beta$-casein. However, opioid 


\section{$\mu \mathrm{mol} / \mathrm{g}$ product}

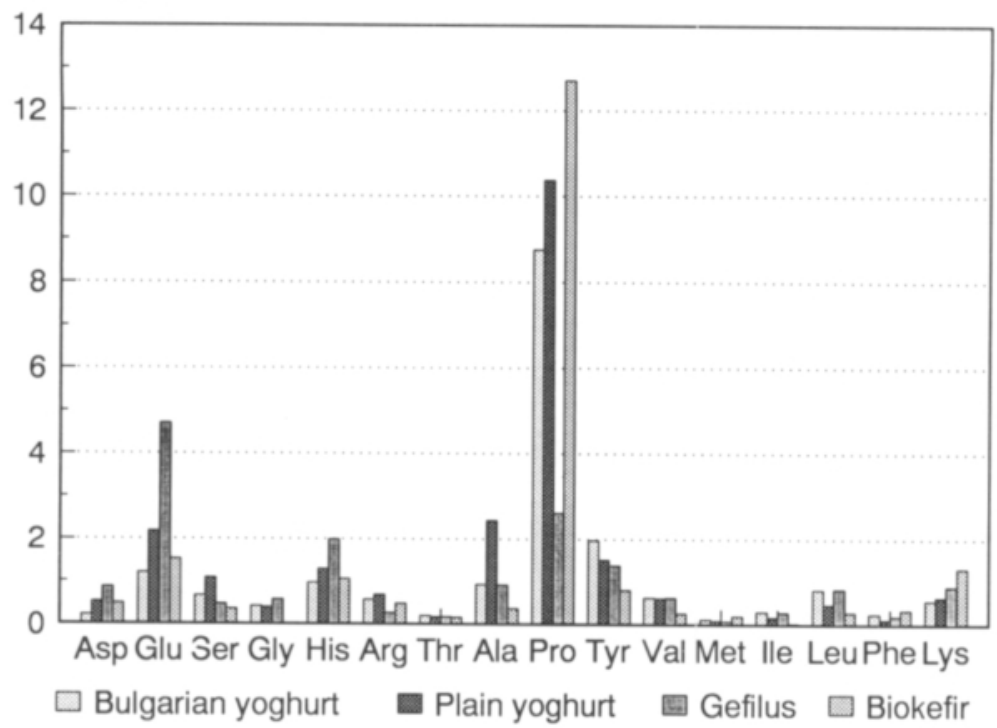

Fig. 9. Free amino acid content ( $\mu \mathrm{mol} / \mathrm{g}$ product) of Bulgarian yoghurt, Plain yoghurt, Gefilus and Biokefir. The three letters amino acid codes used.

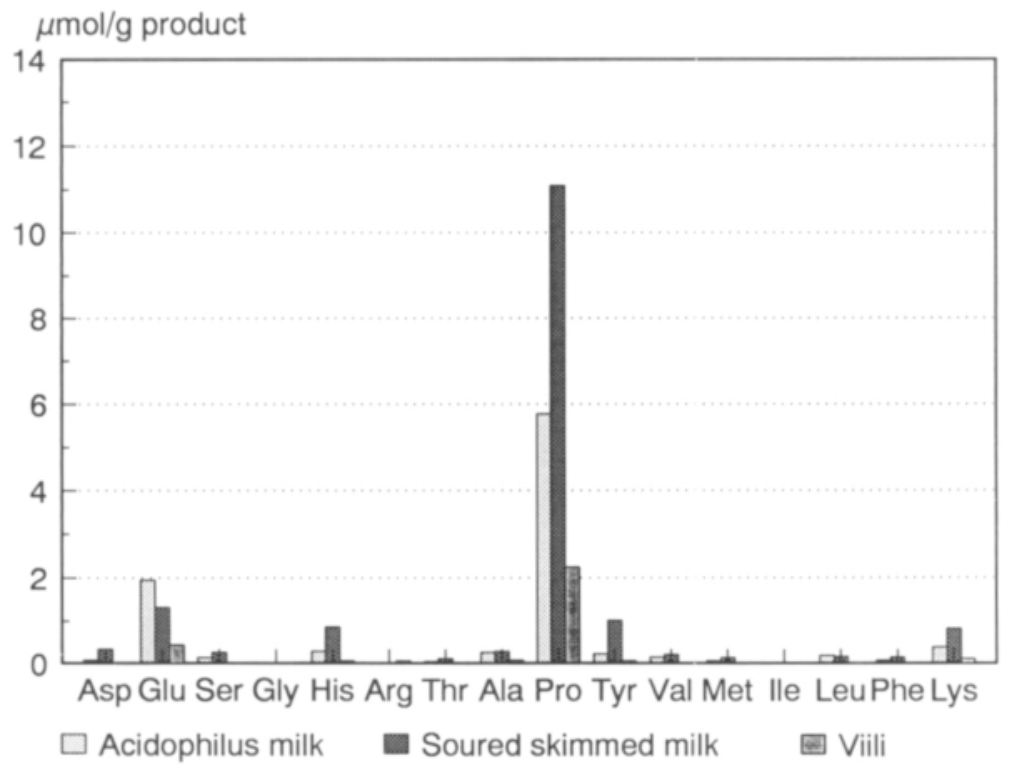

Fig. 10. Free amino acid content ( $\mu \mathrm{mol} / \mathrm{g}$ product) of acidophilus milk, soured skimmed milk and viili. The three letters amino acid codes used. $\beta$-casomorphines ( $\beta-\mathrm{CN}$ f $60-70$ ) were not observed.

Table 3 summarizes the peptides which were identified during the study. Peptides typical for yoghurts include fragments 1-14 from $\alpha_{\mathrm{s} 1 \text {-casein and }}$
47-57, 166-175 and 176-188 from $\beta$-casein. Peptide $\beta-\mathrm{CN}$ 176-188 contains a fragment which, according to MARUYAMA et al. (1985), possesses antihypertensive activity ( $\beta-\mathrm{CN}$ f 177-183). Despite the apparent similarity of the peptide profiles of Bul- 
Table 3. Identified peptide sequences in fermented milk products, 1. Bulgarian yoghurt, 2. Plain yoghurt, 3. Gefilus, 4. Viili, 5. Biokefir, 6. Acidophilus milk, 7. Soured skimmed milk.

\begin{tabular}{llllllll}
\hline Sequence & 1. & 2. & 3. & 4. & 5. & 6. & 7. \\
\hline $\begin{array}{lllll}\alpha_{\mathrm{s}}-\mathrm{CN} \\
1-14\end{array}$ & $\mathrm{x}$ & $\mathrm{x}$ & & & & & \\
$\beta-\mathrm{CN}$ & & & & & & & \\
$1-9$ & & & & $\mathrm{x}$ & $\mathrm{x}$ & & \\
$7-16$ & & & $\mathrm{x}$ & $\mathrm{x}$ & $\mathrm{x}$ & $\mathrm{x}$ & $\mathrm{x}$ \\
$22-28$ & & & & & $\mathrm{x}$ & & $\mathrm{x}$ \\
$44-52$ & & & & $\mathrm{x}$ & $\mathrm{x}$ & $\mathrm{x}$ & \\
$47-57$ & $\mathrm{x}$ & $\mathrm{x}$ & & & $\mathrm{x}$ & & \\
$164-175$ & & & & $\mathrm{x}$ & & $\mathrm{x}$ & \\
$166-175$ & $\mathrm{x}$ & $\mathrm{x}$ & & & & & \\
$169-175$ & & & & $\mathrm{x}$ & $\mathrm{x}$ & $\mathrm{x}$ & $\mathrm{x}$ \\
$176-182$ & & & $\mathrm{x}$ & $\mathrm{x}$ & $\mathrm{x}$ & $\mathrm{x}$ & $\mathrm{x}$ \\
$176-188$ & $\mathrm{x}$ & $\mathrm{x}$ & & & & & \\
$\kappa-\mathrm{CN}$ & & & & & & & $\mathrm{x}$ \\
$161-169$ & & & & & & & \\
\hline
\end{tabular}

garian and plain yoghurt, slight differences exist which are presumably caused by differences in the combination of starter and the manufacturing processes. The peptide profile of Gefilus differs very much from that of both yoghurts. The identified peptides are different and the free amino acid content is also higher than in yoghurts.
There is a certain similarity between the peptide profiles of viili, soured skimmed milk and Gefilus (Figures 3-7). Identical fragments of $\beta$-casein were found in these products. The most common peptides were fragments 7-15, 44-52, 169-175 and 176-182 of $\beta$-casein. Fragment 161-169 from the $\mathrm{C}$-terminal region of $\kappa$-casein appears in soured skimmed milk. This peptide was not identified in any other product. Fragment $22-28$ from $\beta$-casein appears only in kefir and soured skimmed milk. One of the peptides identified in viili and acidophilus milk was $\beta$ - $\mathrm{CN}$ f 164-175.

The effect of plasmin on the peptide profile of the studied fermented milk products seems to be negligible. Its high specificity towards $\alpha_{\mathrm{s} 2}$-casein should be easily recognizable (VISSER et al. 1989, PAHKALA et al. 1989a). The activity is obviously weakened by the high heat treatment of milk and low $\mathrm{pH}$. An additional cause might be the relatively short storage period which may have led to an overlapping of the proteolytic activity of starters with the activity of plasmin. The high heat treatment of milk during the manufacture of all the fermented milk products denaturates the whey proteins and causes the association of $\kappa$-casein and $\beta$-lactoglobulin (DALGLEISH 1990). The effect of these phenomena on the proteolytic end products was, however, not distinguishable in this study.

\section{References}

ALM, L. 1982. The effect of fermentation on nutrients in milk and some properties of fermented liquid milk products. Stockholm, Sweden. (Diss.).

Dalgleish, D.G. 1990. Denaturation and aggregation of serum proteins and caseins in heated milk. J. Agric. Food Chem. 38: 1995-1999.

LemieuX, L. \& Aмıо,, J. 1990. High-performance liquid chromatography of casein hydrolysates phosphorylated and dephosphorylated. I. Peptide mapping. J. Chromatogr.500: 299-321.

Maruyama, S., Nagami, K., Tomizuka, H. \& Suzukı, H.K. 1985. Angiotensin I converting inhibitor derived from an enzymatic hydrolysate of casein. II. Isolation and brady kin-potentiating activity on the uterus and the ileum of rats. Agric.Biol.Chem. 49: 1405-1409.

Miller, I., Martin, H. \& Kandler, O. 1964. Das Aminosäurespektrum von Joghurt. Milchwissenschaft 19: 1825.

Millipore Corporation 1987. Liquid chromatographic ana- lysis of amino acids in feeds and foods using a modification of the Pico-Tag method. Revision.

Pahkala, E., Pihlanto-Leppälä, A., Laukkanen, M. \& AnTILA, V. 1989a. Decomposition of milk proteins during the ripening of cheese. 1. Enzymatic hydrolysis of $\alpha_{\mathrm{s}}$-casein. Meijeritieteellinen Aikakauskirja 47, 1: 39-47.

— , Pihlanto-Leppälä, A., Laukkanen, M. \& Antila, V. $1989 \mathrm{~b}$. Decomposition of milk proteins during the ripening of cheese. 2. Enzymatic hydrolysis of $\beta$-casein. Meijeritieteellinen Aikakauskirja 47, 1: 63-70.

Robinson, R.K. \& TAMIME, A.Y. 1981. Microbiology of fermented milks. In: Robinson, R.K. (ed.). Dairy Microbiology, vol. 2, The Microbiology of Milk Products. Applied Science Publishers, Essex, England. p. 245-277.

TAmime, A.Y. \& Robinson, R.K. 1989. Yoghurt: Science and Technology. 2nd ed., Pergamon Press, Oxford.

Tanev, G. \& Zivkova, A. 1977. Study of short-chain peptides in Bulgarian yoghurt 1. Preparation of peptide maps. Milchwissenschaft 32: 280-282. 
TARR, G.E. 1986. Manual Edman sequencing system. In: Shively, J.E. (ed.). Methods of Protein Microcharacterization, A Practical Handbook. Humana Press, Clifton, New Jersey. p. 155-193.

Visser, S., Slangen, K.J., Alting, A.C. \& Vreeman, H.J. 1989. Specificity of bovine plasmin in its action on bovine $\alpha_{s 2}$-casein. Milchwissenschaft 44: 335-339.
Manuscript received July 1993

\section{Minna Kahala}

Eero Pahkala

Anne Pihlanto-Leppälä

Agricultural Research Centre of Finland

Food Research Institute

FIN-31600 Jokioinen, Finland

\title{
SELOSTUS
}

\section{Hapanmaitotuotteiden peptideistä}

\section{Minna Kahala, Eero Pahkala ja Anne Pihlanto-Leppälä}

\author{
Maatalouden tutkimuskeskus
}

Suomalaisten hapanmaitotuotteiden valkuaisaineiden pilkkoutumista tutkittiin varastoinnin aikana. Tuotteista määritettiin proteolyysiaste sekä eristettiin ja identifioitiin peptidejä peptidikartalta. Suurin proteolyysiaste todettiin biokefiirissä, kun taas suurin proteolyysiasteen muutos todettiin gefilukses- sa. Erot käytetyissä hapatteissa ja valmistusmenetelmissä kuvastuivat tuotteiden peptidikartoissa. Useimmat tunnistetuista peptideistä olivat peräisin $\beta$-kaseiinin $\mathrm{N}$ - tai $\mathrm{C}$-terminaalisesta päästä tai $\alpha_{s 1}$-kaseiinin $N$-terminaalisesta päästä. 